\title{
Kroppens finjusterte jernreguleringssystem
}

Jern er nødvendig for en rekke prosesser i kroppen, og tilførsel av korrekte mengder jern til enhver tid er en forutsetning for opprettholdelse av mange kroppsfunksjoner. I dette nummer av Tidsskriftet presenteres to oversiktsartikler om jern. Berit BorchIohnsen og medarbeidere legger frem en oversikt over jernbalansen (1), mens Tor-Arne Hagve og medarbeidere tar utgangspunkt i sykdommen hemokromatose som er kjennetegnet ved jernoverskudd (2). Artiklene gir et bilde av hvordan den komplekse jernreguleringen er oppbygd og av hvordan sykdom kan oppstå når jernreguleringen går i stå. Til tross for at mange mekanismer for jernregulering i dag er kjent, gjenstår fremdeles en del før vi fullt ut kan forstå jernreguleringens finjusterte nettverk.

Gjennom flere generasjoner har det vært kjent at jern er livsnødvendig for kroppen. Kunnskapen om at både for lite og for mye jern kan være skadelig, er etter hvert blitt akseptert. Globalt sett er jernmangel fortsatt den viktigste årsaken til anemi - en tilstand som representerer et alvorlig helseproblem i store deler av verden. I utviklingsland skyldes jernmangel hovedsakelig underernæring, men infeksjonssykdommer, spesielt hiv- og gastrointestinale infeksjoner, og høyt antall barnefødsler kan føre til store jerntap. Anemi ser ut til å disponere for infeksjoner, mens infeksjoner forsterker anemi. Dette arter seg som en ond sirkel som på sikt tapper kroppen for jern. I industrialiserte land er ikke disse problemstillingene særlig aktuelle, men likevel er det vist at $15 \%$ av norske kvinner i fertil alder har tomme jernlagre. Kvinner med store menstruasjonsblødninger, gravide og ammende kan være utsatt for jernmangelanemi, men også små barn og eldre med lavt kaloriinntak, vegetarianere, samt personer med ensidig kosthold eller som slanker seg, står i faresonen for å utvikle alvorlig jernmangel. Mye tyder på at mange nordmenn kunne hatt fordeler av å beholde jerntilskuddet $i$ brunosten i enda noen år.

Jernoverskudd fører på sin side til at fritt, reaktivt jern danner toksiske radikaler som angriper og destruerer cellulære byggesteiner som proteiner, lipider og DNA-molekyler med alvorlig vevs- og organskade til følge. Det er få medisinske tilstander som gir jernoverskudd. Arvelig hemokromatose er i stor grad koblet til en mutasjon i $H F E$-genet (C282Y) som bidrar til at kroppen akkumulerer jern. I Norge er bærerfrekvensen av mutasjonen i den kaukasiske populasjonen rundt $12-15 \%$, mens homozygot frekvens ligger rundt $0,5-1 \%(1)$. Hyppige transfusjoner, som f.eks. ved talassemier, og inntak av store doser jerntilskudd vil over tid kunne også føre til jernoverskudd.

Kroppen har elegante mekanismer for koordinert jernabsorpsjon, jernresirkulering og mobilisering av jernlagre som sikrer at den viktige jernhemostasen kan opprettholdes, både på systemisk og cellulært nivå. Jernreguleringen er satt inn på mange plan og det benyttes et rikt repertoar av komponenter. Bruk av proteiner i reguleringen er generelt en genistrek. Proteiner har sin opprinnelige oppskrift på gennivå hvor aktiviteten reguleres ved å skru seg av og på. Dette gir mange muligheter for kvantitativ fininnstilling av proteinene. Første kontrollfase er jernopptaket, hvor reguleringsmekanismene må håndtere at mengden og typen jern gjennom føden varierer fra person til person. Cytosolisk jern kan lagres intracellulært ved binding til ferritin eller eksporteres videre til plasma via binding til eksportproteinet ferroportin (3). Sirkulatorisk jern er bundet til bindingsproteinet transferrin, den viktigste jernkilden for de fleste celler og vev. Grad av jernmettet transferrin er en pålitelig indikator for systemisk jernhomøostase.

Leveren er et viktig organ i jernreguleringen. Hepcidin, et lite peptidhormon som produseres i hepatocytter, er vist å være en overordnet jernregulerende komponent (4). Hepcidin kan binde ferroportin i enterocytter, makrofager og hepatocytter, med påfølgende internalisering og degradering av ferroportin. Dette fører til indirekte blokkering av jernabsorpsjonen fra tarmen via redusert eksport til sirkulasjonen, redusert resirkulering av jern fra makrofager og redusert mobilisering av lagret jern fra hepatocyttene med synkende serum-jernkonsentrasjon som endepunkt. Hepcidin spiller dermed en sentral rolle $\mathrm{i}$ jernreguleringen, understreket ved at utslukking av hepcidingenet i mus gir massivt jernoverskudd (5), mens overekspresjon gir alvorlig anemi (6). Kontroll av hepcidinekspresjon, regulert på transkripsjonsnivå, blir derfor svært avgjørende. Kontrollen styres av molekyler som overvåker jernkonsentrasjonen i ulike celler for så å kommunisere med sirkulasjonen. Slike molekyler er bl.a. transferrinreseptor 1 og 2, beinmorfogent protein og den nylig identifiserte hemojuvenil, som alle induserer til hepcidinekspresjon.

Det kan synes som om alle trinn i jernreguleringen biologisk er blitt tatt godt hånd om - trolig en gjenspeiling av hvor viktig riktig jernnivå er. At utskillingen av jern ikke kan reguleres fysiologisk, kan derfor beskrives som et medisinsk paradoks! Uansett hvor stort jernoverskudd kroppen blir utsatt for, er det ikke mulig å aktivere til $ø k t$ jerneksport. I fravær av regulert jernutskilling vil dermed jernabsorpsjonen fra tarmen utgjøre den overordnede kritiske variabel for systemisk jerntilgjengelighet og bæreevne. Hepcidin spiller derfor en svært sentral rolle ved evnen til å regulere utførsel av jern fra flere celletyper. Til tross for at store vitenskapelige funn er gjort på fagfeltet jernhomøostase det siste tiåret, er fortsatt mye uløst. Vil flere mediatorer i jernreguleringen kunne kartlegges? Nyere forskning viser at DNA-sekvensområder vi inntil nylig omtalte som «junk», kan vise seg å ha betydning for biologisk funksjon. Fremtiden vil vise om bidraget fra disse områdene kan være med på å belyse enda flere reguleringsmekanismer innenfor jernbalansen.

\section{Kari Bente Foss Haug}

k.b.foss@medisin.uio.no

Kari Bente Foss Haug (f. 1961), er dr. scient og forsker ved FoU-seksjonen, avdeling for medisinsk biokjemi og klinisk farmakologi, Oslo universitetssykehus, Ullevål.

Oppgitte interessekonflikter: Ingen

\footnotetext{
Litteratur

1. Borch-lohnsen B, Hagve T-A, Hauge A et al. Regulering av jernbalansen. Tidsskr Nor Legeforen 2009: 129: 858-62.

2. Hagve T-A, Åsberg A, Ulvik R et al. Hemokromatose - fra underdiagnostisert kuriositet til folkesykdom. Tidsskr Nor Legeforen 2009; 129: 863-6.

3. Zhang AS, Enns CA. Iron homeostasis: recently identified proteins provide insight into novel control mechanisms. J Biol Chem. 2009; 284: 711-5.

4. Ganz T. Iron hemostasis: fitting the puzzle pieces together. Cell Metab 2008; 7: $88-90$.

5. Nicolas G, Bennoun N, Devaux I et al. Lack of hepcidin gene expression and severe tissue iron overload in upstream stimulatory factor 2 (USF2) knockout mice. Proc Natl Acad Sci USA 2001: 98: 8780-85.

6. Nicolas G, Bennoun N, Porteu A et al. Severe iron deficiency anemia in transgenic mice expressing liver hepcidin. Proc Natl Acad Sci USA 2002; 99 $4596-601$
} 